\title{
Primary cerebral lymphoma: a study of 47 cases probed for Epstein-Barr virus genome
}

\author{
J F Geddes, M B Bhattacharjee, K Savage, F Scaravilli, J E McLaughlin
}

\begin{abstract}
Aims: To determine the prevalence of Epstein-Barr virus genome in primary cerebral lymphomas occurring in the absence of immune suppression.

Methods: Forty eight consecutive patients with lymphomas restricted to the central nervous system were identified, all of whom had had neurosurgical biopsies performed at the National Hospitals for Neurology and Neurosurgery, London. Only five patients had some form of underlying immune deficiency; 43 were apparently normal. The tumours were studied with immunohistochemical markers and by in situ hybridisation, using a biotinylated probe to the internal repeat region of Epstein-Barr virus.

Results: All the lymphomas were $B$ cell in origin. Tumours from the five immunosuppressed patients all showed hybridisation, as did two of the "spontaneous" tumours.

Conclusions: This is the largest series of cerebral lymphomas so far probed for Epstein-Barr virus genome: as more are examined, it is suggested that a small proportion of the tumours from immunocompetent patients will also contain the virus.
\end{abstract}

Lymphomas arising as isolated tumours of the central nervous system are uncommon, their incidence being generally estimated as less than $1.5 \%$ of intracranial neoplasms, ${ }^{1-4}$ and as a result most published series are small.

Interest in these tumours has been revived recently, with the identification of Epstein-Barr virus (EBV) in cerebral lymphomas, ${ }^{5}$ principally in patients with AIDS. ${ }^{67}$ The association between the virus and tumour is less clear in lymphomas that occur in immunologically competent people. We reviewed the surgical biopsy specimens of a large series of primary cerebral lymphomas, almost all of them sporadic tumours, using immunohistochemical markers and DNA in situ hybridisation for EBV genome.

\section{Methods}

A consecutive series of primary cerebral lymphomas was obtained from the neuropathology files of the National Hospitals for Neurology and Neurosurgery, London. Over the period studied (1973-1990 at Maida Vale Hospital and 1979-1990 at Queen Square), a total of
8444 central nervous system tumours were biopsied. Forty eight patients were found in whom the diagnosis of lymphoma restricted to the nervous system could be made with certainty. In four cases post mortem examination confirmed the biopsy specimen diagnosis.

Formalin fixed, paraffin wax embedded tumour obtained at surgery was available in $\mathbf{4 7}$ cases. Sections were routinely stained with haematoxylin and eosin, reticulin, and a panel of immunostains using the peroxidase-antiperoxidase technique. These included: leucocyte common antigen (a pan-white cell marker recognising the CD45 epitope); L26 (directed against the B cell antigen CD20); and UCHL1 (recognising the $\mathrm{T}$ cell differentiation antigen CD45R). All the antibodies were supplied by Dako. The pathological material was classified on the basis of morphology and staining reactions into prognostic groups, according to the criteria of the International Working Formulation sponsored by the National Cancer Institute. $^{8}$

A biotinylated DNA probe to the Bam $H 1 W$ (internal repeat 1) region of the Epstein-Barr virus (EBV) genome (Enzo Diagnostics Inc) was also used on sections of 47 tumours. Hybridisation was visualised by means of an antibiotin antibody.

Sections on poly-L-lysine-coated slides were dewaxed and rehydrated. Endogenous peroxidase activity was inhibited with $3 \%$ hydrogen peroxide in methanol, the sections were then washed in water, rinsed in phosphate buffered saline (PBS) with 5mM EDTA, and digested with proteinase $\mathrm{K}(1 \mathrm{mg} / \mathrm{ml}$ in PBS/EDTA, 15 minutes at $37^{\circ} \mathrm{C}$ ). After further washing with water and PBS/EDTA the hybridisation mixture $(50 \%$ formamide, $5 \%$ dextran sulphate, $2 \times$ SSPE (sodium-saline-phosphate-EDTA) and $500 \mu \mathrm{g} / \mathrm{ml}$ carrier DNA) with biotinylated EBV probe $(15 \mu \mathrm{l} / 100 \mu \mathrm{l}$ hybridisation buffer) was applied. Hybridisation mix $(20 \mu \mathrm{l})$ was added to an average section. The sections were covered with coverslips, then incubated at $92^{\circ} \mathrm{C}$ for six minutes, and hybridisation was allowed to proceed at $37^{\circ} \mathrm{C}$ for two hours. Coverslips were removed with $4 \times$ SSC (sodium citrate, sodium sulphate); slides were then rinsed in $4 \times$ SSC, followed by washing in PBS. Before visualisation, non-specific binding of antibody was blocked with $1 \%$ normal horse serum in PBS. Slides were incubated in rabbit anti-biotin antibody (Enzo), diluted 1 in 200 in PBS for one hour. After rinsing in TRISbuffered saline (TBS), sections were covered with biotinylated swine anti-rabbit antibodies (Dako), diluted 1 in 500 in TBS with $1 \%$ 
Table 1 Working formulation classification of 47 primary cerebral lymphomas

\begin{tabular}{lc}
\hline Low grade tumours: & \\
Small lymphocytic cell & 2 \\
Lymphoplasmacytoid cell & 3 \\
Intermediate grade tumours: & 7 \\
Large cleaved cell & 11 \\
Mixed large and small cleaved cell & 19 \\
Large non-cleaved cell & \\
High grade tumours: & 1 \\
Large cell immunoblastic & 2 \\
Lymphoblastic & 2 \\
Unclassifiable & 47 \\
Total: & \\
\hline
\end{tabular}

normal swine serum, for 30 minutes, followed by incubation in horseradish peroxidase conjugated avidin-biotin complex (Dako) for 30 minutes. Signal was visualised using diaminobenzidine (DAB); sections were counterstained in Meyer's haematoxylin, dehydrated,

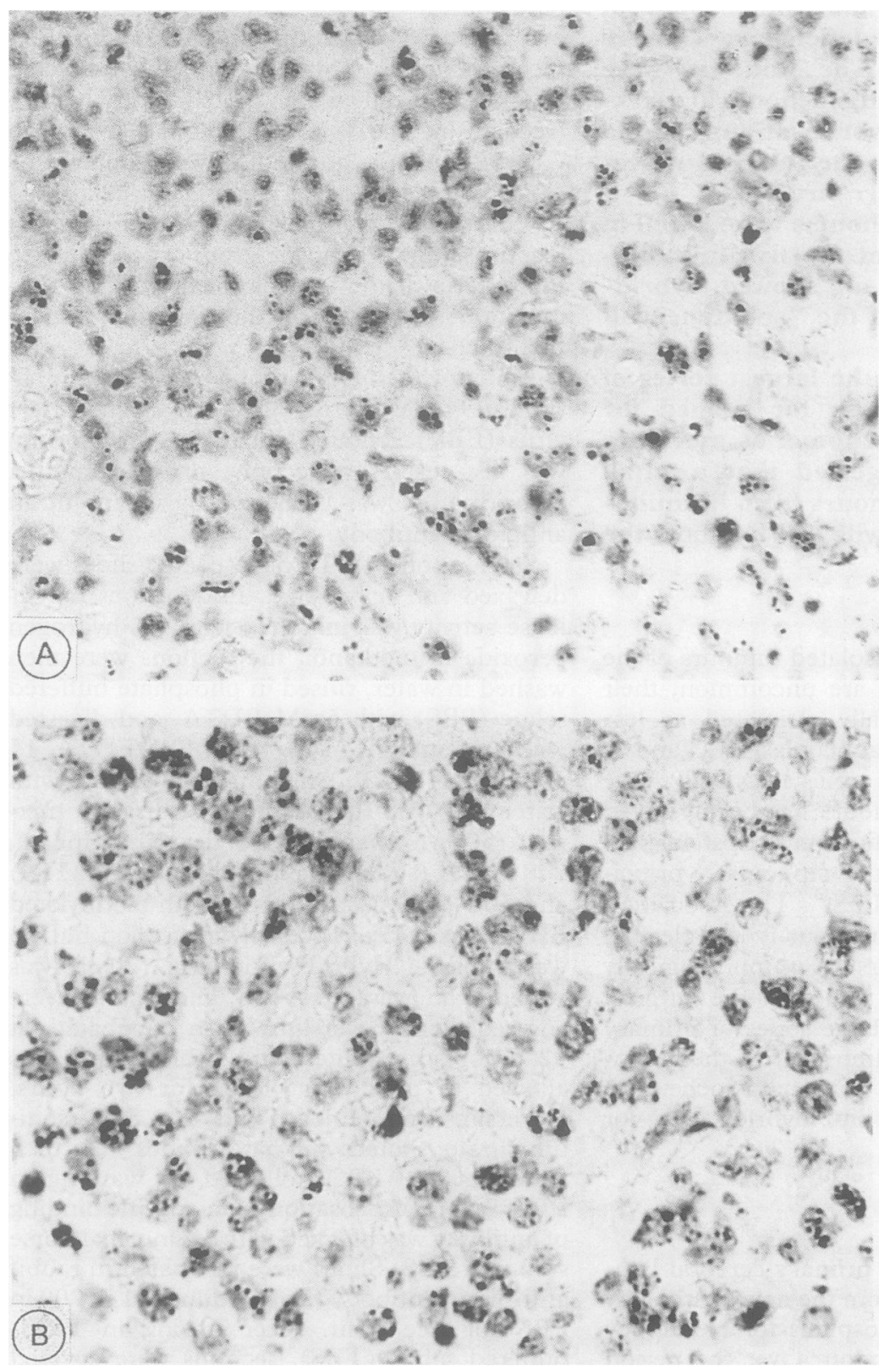

Figure (A) An AIDS-related lymphoma showing hybridisation for EBV genome. (B) $A n$ identical picture is seen in the tumour cells of an immunologically normal patient. cleared and mounted in DPX. Cytomegalovirus (CMV) (Enzo) was used as an irrelevant probe with a similar method.

The probes were validated and showed hybridisation (recognised as granular brown deposits of varying sizes in the nuclei) in all the EBV positive control sections used in this series, which included sections of cells of the Burkitt Raji line, a tongue from a patient with AIDS and oral hairy leucoplakia, and a lymphoma from a renal transplant recipient already known to be harbouring the EBV genome. Appropriate negative controls included digestion with RNAase and DNAase, which were negative. Sections probed for CMV were negative. All cases were examined without knowledge of the clinical details.

\section{Results}

The series comprised 27 men and 20 women. Forty three patients $(91.4 \%)$ had no identifiable immune deficiency; of the rest, four had AIDS, and one was immunosuppressed following a renal transplantation. The mean age at diagnosis for all the patients was 54.4 years (median 55 years), and slightly older (56.8 years, median 58 years) when the five cases with underlying immune deficiency had been discounted.

The anatomical sites most frequently involved were: cerebral hemispheres $(n=20)$, cerebellum $(n=4)$, corpus callosum $(n=3)$, basal ganglia $(n=2)$, cerebellopontine angle $(n=2)$, brain stem $(n=1)$, optic nerves $(n=1)$ and cervical cord $(n=1)$. Twenty seven per cent of tumours were found to be multifocal in distribution, and three of the five immunosuppressed patients had multifocal lesions.

The presence of extracerebral disease had been actively excluded in most patients, principally by bone marrow biopsy and abdominal computed tomography or ultrasound scan, and all tumours were considered to be confined to the central nervous system.

HISTOLOGICAL FINDINGS

The main patterns of growth in our series were typical: all were diffuse lymphomas, originating in perivascular spaces, and spreading to form confluent parenchymal masses. In two tumours the morphology was too poor to permit description, but the remaining 45 were classified according to the International Working Formulation criteria, and the results are given in table 1 .

Immunohistochemical studies were limited by the availability of markers working on paraffin wax embedded material, and in most cases consisted only of a pan-white cell marker, and $B$ cell and $T$ cell markers. Without exception, all cases were of $B$. cell type, in which a small but variable proportion of the cells were $T$ lymphocytes and presumably reactive in nature.

With the use of the biotinylated EBV specific probe, the tumour cells in all five cases of cerebral lymphoma in immunosuppressed patients were strongly positive (figure). The 
Table 2 Tumours showing positive EBV hybridisation

\begin{tabular}{llc}
\hline & $\begin{array}{l}\text { Number of } \\
\text { cases }\end{array}$ & $\begin{array}{l}\text { Strength of } \\
\text { reaction }\end{array}$ \\
\hline Immunosuppressed patients: & 2 & +++ \\
& 2 & ++ \\
Immunocompetent patients: & 1 & + \\
& 1 & +++ \\
& 1 & ++ \\
\hline
\end{tabular}

$+++=>60 \%$ of tumour cells positive; $++=20-60 \%$ of tumour cells positive; $+=<20 \%$ of tumour cells positive (Bashir et al $)$

signal observed was in the nuclei of tumour cells only, and similar to the staining seen in the controls. In each case we attempted to quantify the positivity seen, using a three point scale. The results are shown in table 2 . Granule size and numbers varied from cell to cell. Some nuclei contained very small granules only detectable with an oil immersion lens; most positive nuclei were easily seen and counted with a $\times 40$ objective. In two of the positive cases fragments of unaffected brain were also present in the biopsy sample, and in these areas no cells showed hybridisation.

In addition to these cases, three further tumours in patients with no underlying disease also contained EBV genome. In one of these only two tumour cells in a small biopsy specimen showed hybridisation, and the importance of this finding must be in doubt, especially as no further cells showed positive signal when additional sections were stained. In the two other tumours, however, many cells per high power field were positive (figure and table 2).

\section{Discussion}

The association between the lymphotropic Epstein-Barr virus and conditions such as African Burkitt's lymphoma, nasopharyngeal carcinoma, and a number of benign and malignant B cell lymphoproliferative disorders is well recognised. ${ }^{9-11}$ Population surveys, in which lymphoma patients have been shown to have higher titres of EBV capsid antigen than controls, ${ }^{1213}$ have been complemented by studies using DNA probes for EBV genome. Such studies have identified virus in tissue biopsy specimens from several different lymphoproliferative conditions, including malignant lymphoma. ${ }^{14-22}$ Isolated clinical reports have also suggested a relation between EBV and lymphoma. ${ }^{1723}$

Recent work has provided further evidence that there is an association between EpsteinBarr virus and primary lymphoma of the brain. Several studies have shown the presence of EBV genome in the malignant cerebral lymphomas of immunosuppressed patients, either by hybridisation methods using extracted host DNA, or by in situ hybridisation on tissue sections. ${ }^{6} 72425$ Cerebral lymphomas arising in patients with no obvious underlying disease have been less well studied in this respect. The single case of Hochberg was the first to be reported. ${ }^{5}$ Murphy and colleagues probed tumours from 24 immunologically normal patients, using a panel of three probes to different sequences in the EBV genome. ${ }^{26}$ Eleven of their tumours showed positive hybridisation in situ, most consistently with the Bam $H 1 W$ repeat sequence probe. These authors comment that their failure to demonstrate viral genome in the remaining 13 cases was possibly due to poor tissue fixation or preservation.

Using the same internal repeat sequence to probe our 47 malignant cerebral lymphomas, we have shown positive hybridisation in all five cases where there was underlying immune deficiency, but otherwise convincingly in only two of the 42 apparently normal patients $(4 \cdot 8 \%)$. Poor fixation or tissue preservation may occasionally present problems, particularly with stereotactic biopsy material from brain tumours, and two of the specimens we investigated did show very poor cellular morphology. We do not feel, however, that this accounts for our inability to demonstrate the presence of virus in most of our lymphomas. Others have failed to get positive hybridisation in tumours arising in apparently immunocompetent patients, while achieving a high detection rate in tumours from immune deficient patients. ${ }^{61524}$ The 26 lymphomas examined by Nakleh et al included 11 primary cerebral lymphomas; all three from immunosuppressed patients contained EBV genome, and one of the eight tumours from immunologically normal patients was also found to be positive. ${ }^{27}$ Our results, from the largest series of "spontaneous" cerebral lymphomas so far studied with in situ hybridisation, are more in line with the findings of these authors, rather than with those of Murphy et al. It is likely that as more of these sporadic cerebral lymphomas are examined, only a small proportion will prove to contain EBV, a view shared by List et al. $^{28}$

When EBV genome is found to be present in a lymphoma, the question is whether the virus causes the tumour, or whether it is merely infecting it secondarily. That EBV may induce such neoplasms was strongly suggested by the cases of Pattengale ${ }^{23}$ and Hanto. ${ }^{17}$ The use of biotinylated probe with a haematoxylin counterstain enabled us to establish that the EBV genome was present in neoplastic cells rather than reactive lymphocytes, although positive labelling did not correlate with any particular histological subtype of tumour. The demonstration of viral genome in tumour cells but not in unaffected brain, by us and by Hochberg, ${ }^{59}$ also suggests an aetiological rather than "passenger" role for the virus. However, because this was largely a retrospective study of neurosurgical material we were not able to probe either peripheral blood lymphocytes or peripheral tissues for EBV, which has been done successfully in patients with systemic lymphoma. $^{30}$ Clearly, the absence of EBV genome in most sporadic cerebral lymphomas indicates that the virus is not vital for its development.

Finally, all our immunosuppressed patients had a very rapid history of neurological deteri- 
oration and a uniformly dismal prognosis (range one week to two months); the two immunocompetent patients with positive tumours were both alive at the time of writing, their survival from diagnosis being almost three years and 10 months, respectively. Because of the small numbers involved, we were not able to show any relation in the nonimmunocompromised lymphomas between the amount of hybridisation signal and the patient's subsequent clinical course, but further study of these two patients is planned when they return for follow up visits.

The numbers of spontaneous primary cerebral lymphoma currently seen remain small in comparison with other brain neoplasms, and unlike the immunosuppressed tumours, few of them have so far been examined for the presence of EBV genome. Issues such as the association between cerebral and systemic nodal and extranodal lymphomas, between sporadic tumours and the immune suppressed variety, and the role of EBV have still to be addressed satisfactorily.

We are grateful to Dr R O Barnard, Dr T Revesz, Dr S Hamilton-Dutoit, and Ms Elizabeth Sinclair for their advice and help, to Miss Rosalind Sim for expert technical assistance, and to the Mick Shields Cancer Charity for generous financial support (JG)

1 Hochberg FH, Miller DC. Primary central nervous system lymphoma. F Neurosurg 1988;68:835-53.

2 Jellinger K, Slowik F. Primary non-Hodgkin's lymphoma of the central nervous system. In: Walker MD, Thoma DGT, eds. Biology of brain tumour. Boston: Martinus Nijhoff, 1986:145-52.

3 O'Neill BP, Illig JJ. Primary central nervous system lymphoma. Mayo Clin Proc 1989;64:1005-20.

4 Schiffer D, Chiò A, Giordana MT, et al. Primary lymphomas of the brain: a clinicopathologic review of 37 cases. Tumori 1987;73:585-92.

5 Hochberg FH, Miller G, Schooley RT, Hirsch MS, Feorino $P$, Henle W. Central nervous system lymphoma related to Epstein-Barr virus. $N$ Engl $₹$ Med 1983;309:745-8.

6 Bashir RM, Hochberg FH, Harris NL, Purtilo D. Variable expression of Epstein-Barr virus genome as demonstrated by in situ hybridization in central nervous system lymphomas in immunocompromised patients. Mod Pathol 1990;3:429-34.

7 Hamilton-Dutoit SJ, Karkov J, Franzmann MB, Pallesen G AIDS-related central nervous system lymphoma. In: Rac P, Haase AT, Gluckmann JC, eds. Modern pathology of AIDS and other retroviral infections. Basel: Karger, 1990:110-29.

8 Non-Hodgkin's Lymphoma Pathologic Classification Project. National Cancer Institute sponsored study of classifications of Non-Hodgkin's lymphomas. Cancer 1982;49:2112-35

9 Okano M, Thiele GM, Davis JR, Grierson HL, Purtilo DT. Epstein-Barr virus and human disease: recent advances in Epstein-Barr virus and human disease: recent

10 Purtilo DT. Epstein-Barr-virus-induced oncogenesis in immune-deficient individuals. Lancet 1980;i:300-3.

11 Schmader KE, van der Horst CM, Klotman ME. EpsteinBarr virus and the elderly host. Rev Infect Dis 1989; 11:64-73.
12 Evans AS, Carvalho RPS, Frost P, Jamra M, Pozzi DHB Epstein-Barr virus infections in Brazil. II. Hodgkin's Epstein-Barr virus infections
disease. fNCI 1978;61:19-26.

13 Hesse J, Levine PH, Ebbesen P, Connelly RR, Mordhorst CH. A case control study on immunity to two EpsteinBarr virus-associated antigens, and to herpes simplex virus and adenovirus in a population-based group of patients with Hodgkin's disease in Denmark, 1971-73. Int $\mathcal{F}$ Cancer 1977;19:49-58.

14 Anagnostopoulos I, Herbst H, Niedobitek G, Stein H. Demonstration of monoclonal EBV genomes in Hodgkin's disease and $\mathrm{KI}-1$ positive anaplastic large cell lymphoma by combined Southern blot and in situ hybridization. Blood 1989;74:810-16.

15 Hamilton-Dutoit SJ, Pallesen G. Demonstration of EpsteinBarr viral genomes in routine paraffin sections of lymBarr viral genomes in routine paraffin sections of lymtion. In: Fenoglio-Preisen C, Wolff M, Rilke F, eds. tion. In: Fenoglio-Preisen C, Wolff M, Rilke F, eds.
Progress in surgical pathology, vol XII. Philadelphia: Field \& Progress in surgical patholog

16 Hamilton-Dutoit SJ, Pallesen G, Franzmann MB, et al. AIDS-related lymphoma: histopathology, immunophenotype, and association with Epstein-Barr virus as demonstrated by in situ nucleic acid hybridization. $\mathrm{Am}$ f Pathol 1991;138:149-63.

17 Hanto DW, Frizzera G, Gajl-Peczalska, et al. Epstein-Barr virus-induced B-cell lymphoma after renal transplantation. $N$ Engl $₹$ Med 1982;306:913-18.

18 Katz BZ, Raab-Traub N, Miller G. Latent and replicating forms of Epstein-Barr virus DNA in lymphomas and forms of Epstein-Barr virus DNA in lymphomas and
lymphoproliferative diseases. If Infect Dis 1989;160: lymphop

19 Niedobitek G, Hamilton-Dutoit S, Herbst H, et al. Identification of Epstein-Barr virus-infected cells in tonsils of acute infectious mononucleosis by in situ hybridization. Hum Pathol 1989;20:796-9.

20 Pallesen G, Hamilton-Dutoit SJ, Rowe M, Young LS. Expression of Epstein-Barr virus latent gene products in tumour cells of Hodgkin's disease. Lancet 1991; 337:320-2.

21 Saemundsen AK, Berkel AI, Henle W, et al. Epstein-Barrvirus-carrying lymphoma in a patient with ataxia-telangiectasia. Br Med $\mathscr{f} 1981 ; 282: 425-7$.

22 Saemundsen AK, Purtilo DT, Sakamoto $\mathrm{K}$, et al. Documentation of Epstein-Barr virus infection in immunodeficient patients with life-threatening lymphoproliferative diseases by Epstein-Barr virus complementary RNA/DNA and by Epstein-Barr virus complementary RNA/DNA and viral DNA 4237 .

23 Pattengale PK, Taylor CR, Panke T, et al. Selective immunodeficiency and malignant lymphoma of the cenral nervous system: possible relationship to the Epstein Barr virus. Acta Neuropathol 1979;48:165-9.

24 Bashir RM, Harris NL, Hochberg FH, Singer RM. Detection of Epstein-Barr virus in CNS lymphomas by in-situ hybridization. Neurology 1989;39:813-17.

25 Rosenberg NL, Hochberg FH, Miller G, KleinschmidtDeMasters BK. Primary central nervous system lymphoma related to Epstein-Barr virus in a patient with acquired immune deficiency syndrome. Ann Neurol 1986;20:98-102.

26 Murphy JK, Young LS, Bevan IS, et al. Demonstration of Epstein-Barr virus in primary brain lymphoma by in situ DNA hybridisation in paraffin wax embedded tissue. $\mathcal{F}$ Clin Pathol 1990;43:220-3.

27 Nakhleh RE, Manivel C, Copenhaver CM, Sung JH Strickler JG. In situ hybridization for the detection of Epstein-Barr virus in central nervous system lymphomas. Cancer 1991;67:444-8.

28 List AF, Greer JP, Cousar JP, et al. Primary brain lymphoma in the immunocompetent host: relation to Epstein-Barr virus. Mod Pathol 1990;3:609-12.

29 Various Authors. Case records of the Massachusetts General Hospital. Weekly clinicopathological exercises. Case 42-1986. N Engl ₹ Med 1986;315:1079-86.

30 Shibat D, Weiss LM Nathwani BN, Brynes RK, Levine AM. Epstein-Barr virus in benign lymph node biopsies from individuals infected with the human immunodeficiency virus is associated with concurrent or subsequent development of non-Hodgkin's lymphoma. Blood 1991;77:1527-33. 